Türkiye Tarımsal Araştırmalar Dergisi
dergipark.gov.tr/tutad $\begin{aligned} & \text { Turk J Agric Res } \\ & \text { 2018, 5(1): 40-44 } \\ & \text { O TÜTAD } \\ & \text { ISSN: 2148-2306 } \\ & \text { e-ISSN: 2528-858X } \\ & \text { doi: 10.19159/tutad.337577 }\end{aligned}$

\title{
Ak Üçgül (Trifolium repens L.) Populasyonlarında Genetik Çeşitliliğin Belirlenmesi
}

\author{
Gürkan DEMIRKOL", Nuri YILMAZ \\ Ordu Üniversitesi, Ziraat Fakültesi, Tarla Bitkileri Bölümü, Ordu, TÜRKIYE
}

\begin{tabular}{ll}
\hline \multicolumn{1}{c}{ Geliş Tarihi/Received: 11.09 .2017} & Kabul Tarihi/Accepted: 06.01.2018 \\
\hline ORCID ID (Yazar strasına göre / by author order) & \\
\hline Dorcid.org/0000-0003-0033-8039 & (Dorcid.org/0000-0002-0597-6884 \\
\hline "Sorumlu Yazar/Corresponding Author: gurkandemirkol@oduedu.tr
\end{tabular}

"Sorumlu Yazar/Corresponding Author: gurkandemirkol@odu.edu.tr

Özet: Sürdürülebilirlik ancak sahip olunan genetik kaynakların kullanımı ve korunması ile mümkün olabilmektedir. Ak üçgül (Trifolium repens L.) ülkemiz meralarında, park ve bahçe alanlarında yaygın olarak bulunan çok yıllık bir baklagil yem bitkisi olmakla birlikte önemli bir genetik hazine kaynağıdır. Bu çalışma ülkemizin yedi ilinden farklı yüksekliklerden toplanan ak üçgül populasyonlarının genetik farklılıklarının belirlenmesi amacıyla yürütülmüştür. Çalışma kapsamında toplanan on beş populasyonun genetik farklılıklarının belirlenmesinde altı adet Basit Dizi Tekrarları (SSR) markörü kullanılmıştır. Çalışma sonucunda 56 allel belirlenmiştir. Genetik akrabalıkların görülmesi amaçlı oluşturulan dendrogramda populasyonlar üç grup altında toplanmışlardır. Elde edilen sonuçlara göre, özellikle yüksek rakımlı duraklardan toplanan populasyonların çoğunlukla aynı grup içerisinde yer aldıkları görülmüştür. Bu durum toplanan örneklerdeki genetik çeşitliliğin coğrafi dağılım ilişkisini ortaya koymuştur. Sonuç olarak, ak üçgül sslahı çalışmalarında gerekli materyali sağlama açısından ülkemizin zengin bir genetik çeşitliliğe sahip olduğu anlaşılmıştır.

Anahtar Kelimeler: Genetik farklılık, mikrosatelit, polimorfizm

\section{The Determination of Genetic Diversity in White Clover (Trifolium repens L.) Populations}

\begin{abstract}
Sustainability can only be achieved through the use and protection of genetic resources. White clover (Trifolium repens $\mathrm{L}$.), a perennial legume forage grass, is also an important genetic resource and widely found in grasslands, parks and gardens in many regions of Turkey. This study was conducted to determine the genetic diversity of white clover populations collected from different altitudes on seven provinces of Turkey. Six Simple Sequence Repeats (SSR) molecular markers were used to estimate genetic diversity in fifteen populations collected for the study. In the study, 56 alleles were detected. Populations were gouped as three clusters in the dendogram created to see genetic relationships. According to results, especially population collected from high altitudes were mostly in the same group. This revealed the interaction between geographical distribution and genetic diversity in the collected samples. As a result, it was understood that our country has a rich genetic diversity to provide the necessary material in the white clover breeding.
\end{abstract}

Keywords: Genetic difference, microsatellite, polymorphism

\section{Giriş}

Sahip olunan doğal kaynakların değerlendirilerek kullanılması, nüfusun hızla artış gösterdiği günümüz dünyasının başlıca ihtiyaçlarındandır. Bir ülkenin sahip olduğu doğal bitki türleri, o bölgede yetiştiriciliği yapılan kültür bitkilerinin sorunlarının ortadan kaldırılmasında, özelliklerinin iyileştirilmesinde, daha yüksek verimli, daha kaliteli ve daha dayanıklı yeni çeşitlerin geliştirilmesinde muhakkak en önemli role sahip genetik materyallerdir. 
Sürdürülebilirlik kavramının ne denli öneme sahip olduğunun henüz yeni farkına varıldı̆̆ 1 günümüzde, bu genetik materyallerin korunması o ülkede yaşayan herkes için önemli bir görev haline gelmiştir. Yetiştikleri bölgeye tamamen adapte olan bu genetik materyaller, günümüzde ve gelecekte yapılacak ıslah çalışmaları için yadsınamaz ve paha biçilemez bir değere sahiptir.

Yapılan son düzenlemelere rağmen Türkiye'de, hala kaliteli kaba yem açığı bulunmaktadır. Bu nedenle kültürü yapılan diğer tarla bitkileri ile rekabete girebilecek, üstün özelliklere sahip yeni yem bitkisi türlerinin geliştirilerek üretimin artırılması ve bunun neticesinde tarla bitkileri içerisindeki yem bitkisi ekim alanlarının diğer gelişmiş ülkelerde olduğu gibi istenilen seviyeye yükseltilmesi ülkemiz adına büyük bir kazanç olacaktır (Açıkgöz ve ark., 2005; Gündüz, 2013). Yem bitkilerine verilen önemin yetersizliği sebebiyle hayvancılığın sekteye uğraması ve bunun neticesinde insan beslenmesinde çok önemli role sahip et ve süt tüketiminin ülkemiz genelinde azalması sonrası yaşanan durum ortadadır.

Son yıllarda deoksiribonükleik asit (DNA) teknolojisinin gelişimi ile birlikte DNA düzeyindeki markörler genetik çalışmalarda hızlı şekilde yerini almıştır (Toro ve ark., 2009). Genetik çeşitliliğin belirlenmesi, genetik kaynakların korunması ve bunlardan yararlanılması amaçlı faydalanılan bir araştırmadır. Koruma işlemi sınırlı olduğu için hangi populasyonların öncelikli olarak korunması gerektiğinin belirlenmesi gerekmektedir (Mercan, 2010).

Ak üçgül (Trifolium repens L.), dünya genelinde geniş bir yayılış alanı gösteren, genellikle otlatma amacıyla kullanılan, besleyici değeri oldukça yüksek olan çok önemli bir baklagil yem bitkisidir. Yatık gelişmesi ve stolon yapıya sahip olması nedeniyle otlatma ve çiğnenmeye karşı oldukça dayanıklı olan ak üçgül, yem bitkisi üretiminde vazgeçilemez bir yere sahiptir (Açıkgöz, 2001; Acar ve Ayan, 2012).

Bugüne kadar ak üçgülde genetik çeşitliliğin belirlenmesine yönelik yapılan araştırmalar yetersiz düzeydedir. Konu ile ilgili yapılan araştırmalarda ak üçgül bitkisinin önemli düzeyde çeşitlilik gösterdiği ifade edilmiştir (Finne ve ark., 2000; Gustine ve ark., 2002; Jones ve ark., 2003; Treuren ve ark., 2005; George ve ark., 2006; Zhang ve ark., 2010). Ak üçgül bitkisinin genetik olarak çeşitlilik göstermesi sonucu, çeşit geliştirme amaçlı ıslah çalışmalarında bu çeşitlilikten faydalanıldığ 1 ve verim, kalite ve dayanıklılık düzeyinde başarılı sonuçlar alındığ belirtilmektedir (Zhang ve ark., 2010; Smýkal ve ark., 2015). Yem bitkileri üretiminde öncelikli hedefin, diğer tarla bitkileri ile rekabet edebilecek düzeyde çeşit geliştirmek olması gereken ülkemiz tarımında; mevcut çeşitliliğin belirlenip bu zenginlikten en iyi düzeyde faydalanılabilmesi, çok büyük önem arz etmektedir.

Türkiye'nin hemen hemen her yerinde bulunan ak üçgül bitkisi ile, genetik çeşitlilik anlamında yeterince çalışılmamış olması neticesinde yürütülmesine karar verilen bu araştırmada; Türkiye'nin farklı illerinden toplanan ak üçgül (Trifolium repens L.) populasyonlarının genetik farklılıklarının belirlenmesi amaçlanmıştır.

\section{Materyal ve Yöntem}

\subsection{Materyallerin toplanması}

Belirlenen populasyonlara ait genç yaprak örnekleri genetik çeşitliliğin belirlenmesi amaçlı materyal olarak kullanılmıştır. Örneklerin toplanması 2017 yılı Mayıs ayında bitkinin çiçeklenme döneminde gerçekleşmiştir. Her bir populasyon için 20 adet yaprak örneği toplanmıştır. Toplanan örnekler analiz öncesi -80 ${ }^{\circ} \mathrm{C}$ 'de muhafaza edilmiştir. Araştırmada kullanılan 15 adet ak üçgül populasyonunun toplandığ 1 yerlere ait bilgiler Tablo 1'de gösterilmiştir.

Tablo 1. Populasyonların toplandığ yerlere ait bilgiler

\begin{tabular}{llcc}
\hline $\begin{array}{c}\text { Toplandığ1 } \\
\text { il }\end{array}$ & $\begin{array}{c}\text { Toplandığ1 } \\
\text { ilçe }\end{array}$ & $\begin{array}{c}\text { Toplandığ } \\
\text { yükseklik }(\mathrm{m})\end{array}$ & $\begin{array}{c}\text { Çalışma } \\
\text { kodu }\end{array}$ \\
\hline \multirow{3}{*}{ Çanakkale } & Eceabat & 22 & Ç1 \\
& Yenice & 231 & Ç2 \\
& Bayramiç & 610 & Ç3 \\
\hline \multirow{2}{*}{ Denizli } & Honaz & 636 & D1 \\
& Çal & 851 & D2 \\
\hline \multirow{2}{*}{ Gaziantep } & Şehitkamil & 825 & G1 \\
& Nizip & 489 & G2 \\
\hline \multirow{2}{*}{ Konya } & Çumra & 1015 & K1 \\
& Seydişehir & 1108 & K2 \\
\hline \multirow{2}{*}{ Ordu } & Altınordu & 57 & O1 \\
& Ulubey & 633 & O2 \\
& Kabadüz & 1622 & O3 \\
\hline \multirow{2}{*}{ Rize } & İkizdere & 755 & R1 \\
& Ardeşen & 1344 & R2 \\
\hline \multirow{2}{*}{ Van } & Erciş & 1588 & V1 \\
\hline
\end{tabular}

\subsection{Bitki örneklerinde genomik DNA} izolasyonu

Çiçeklenme döneminde toplanan materyallerde genomik DNA izolasyonu Lefort ve ark. (1998) tarafından bildirilen yönteme göre yapılmıştır. Elde edilen genomik DNA'ların, saflık değerleri ve miktarları önce kontrol amaçlı agaroz jelde çalışılmış, daha sonra ise spektrofotometre kullanılarak belirlenmiştir. 


\subsection{Kullanılan SSR primerler}

Araştırmada kullanılan SSR primerler daha önce farklı araştırıcılar tarafından kullanılan ve başarılı sonuçların alındığı primerlerdir (George ve ark., 2006; Zhang ve ark., 2010). Kullanılan primerler Tablo 2'de verilmiştir.

\subsection{SSR allel bölgelerinin PCR ile çoğaltılması}

Çalışma için optimize edilmiş Polimeraz Zincir Reaksiyonu (PCR) koşullarına ait reaktiflerin yoğunluk ve miktarları Tablo 3'te, sicaklık döngüsel düzeni ise Tablo 4'te verilmiştir.

Tablo 2. Çalışmada kullanılan primerlere ait bilgiler

\begin{tabular}{cll}
\hline \multirow{2}{*}{ Orijinal isim } & \multicolumn{1}{c}{ İleri } & \multicolumn{1}{c}{ Primer dizilişi } \\
\hline TRSSRA02H09 & CCACAACTACAAGTAGGTTT & CGTGAATGGTGTTCTATTCT \\
TRSSRA01H11 & AGAAAGGTGAATGATGAAA & TCTAATTCTTCCAATAGGG \\
TRSSRA01C10 & GTACCTGGAAATGTTGATT & GAGCAGCCATGACCTCTG \\
TRSSRB01B05 & AGTGCATACTCAGAGTGAGTGATT & GTTCTAGTAGTTGGATCGTTCTG \\
TRSSRB01E07 & TTTTGTCTAATTGCAGAACCATGG & TTAAGTAACAGGTTGATGCGTAC \\
TRSSRA04B12 & TGGAGTGATGAAGCACAGACACTA & ATGCCCAAATTGAATAATGATGTC \\
\hline
\end{tabular}

Tablo 3. Optimize edilmiş PCR koşulları için gerekli reaktiflerin yoğunluk ve miktarları

\begin{tabular}{lcc}
\hline Reaktif & Yoğunluk & Miktar \\
\hline Genomik DNA & $100 \mathrm{ng} / \mu \mathrm{l}$ & $1 \mu \mathrm{l}$ \\
İleri primer & $2.5 \mathrm{pmol}$ & $1 \mu \mathrm{l}$ \\
Geri primer & $2.5 \mathrm{pmol}$ & $1 \mu \mathrm{l}$ \\
$\mathrm{ddH}_{2} \mathrm{O}$ & & $17 \mu \mathrm{l}$ \\
\hline
\end{tabular}

Tablo 4. Optimize edilmiş PCR sıcaklık döngüsel düzeni

\begin{tabular}{lccc}
\hline İslem & Sicaklik $\left({ }^{\circ} \mathrm{C}\right)$ & Süre & Döngü \\
\hline Öncül & 95 & $5 \mathrm{dk}$ & 1 \\
denatürasyon & 95 & $30 \mathrm{sn}$ & \\
Denatürasyon & 57 & $30 \mathrm{sn}$ & 35 \\
Bağlanma & 72 & $30 \mathrm{sn}$ & \\
Uzaman & 72 & $5 \mathrm{dk}$ & 1 \\
Son uzaman & 4 & $\infty$ & \\
Saklama & & \\
\hline
\end{tabular}

2.5. Agaroz jel elektroforez yöntemi ile ayrımlanmanın sağlanması ve skorlama

Lokuslara ait PCR ürünleri \% 2.5'lik agaroz jel elektroforezinde $60 \mathrm{~V}$ 300A şartlarında 6 saat koşturulmuştur. Bant ağırlık gözlemi için 100 bp DNA ladder kullanılmıştır. Elde edilen jel görüntüleri sonrasında verisel skorlama işlemi gerçekleştirilmiştir.

\subsection{Kümeleme analizi}

Araştırmada, NTSYSpc v2.11 programı ile Aritmetik Ortalamaları Kullanan Tartısız Eş-Grup Yöntemi (UPGMA)'ne göre populasyonların kümeleme analizleri yapılmış ve dendrogramları çıkarılmıştır.

\section{Bulgular ve Tartışma}

Tablo 5 incelendiğinde; çalışma sonucunda toplam 56 allel tespit edilmiş olup, lokus başına ortalama allel sayıs1 9.33 olarak bulunmuştur. $\mathrm{Bu}$ değer yüksek allel çeşitlilik olduğunu göstermektedir. Çalışmada en çok allel gösteren mikrosatelit lokusu 14 allel ile TRSSRA01C10 primerinde görülürken, en az allel gösteren lokus 5 allel ile TRSSRA01H11 primerinde görülmüştür (Tablo 5). Çalışmada kullanılan bütün primerlerin polimorfik özellik gösterdikleri tespit edilmiştir.

Tablo 5. Çalışmada kullanılan primerlerin PIC değerleri ve allel sayıları

\begin{tabular}{ccc}
\hline Primer adı & PIC değeri & $\begin{array}{c}\text { Allel } \\
\text { say1s1 }\end{array}$ \\
\hline TRSSRA02H09 & 0.825 & 8 \\
TRSSRA01H11 & 0.774 & 5 \\
TRSSRA01C10 & 0.924 & 14 \\
TRSSRB01B05 & 0.804 & 7 \\
TRSSRB01E07 & 0.892 & 11 \\
TRSSRA04B12 & 0.961 & 11 \\
\hline
\end{tabular}

Araştırmada, en yüksek polimorfizm bilgi içeriği (PIC) değeri 0.961 ile TRSSRA04B12 primerinde bulunurken, en düşük PIC değeri ise 0.774 ile TRSSRA01H11 primerinde saptanmıştır (Tablo 5).

Daha önce yapılmış olan çalışmalarda örneklerin toplandığı bölgenin büyüklüğüne paralel olarak genetik farklılığın artmış olduğu görülmektedir. Mevcut araştırmada, elde edilen çeşitlilik daha büyük alanlarda yapılan çalışmalarda elde edilen çeşitliliğe benzer sonuçlar verirken (Gustine ve ark., 2002), benzer veya daha küçük alanlarda yapılan çalışmalarda elde edilen çeşitliliğin üzerinde yer almıştır (Treuren ve ark., 2005). Çalışma neticesinde ülkemizin ak üçgül populasyonları açısından zengin bir genetik havuza sahip olduğunun saptanmış olması, yem bitkileri üretimi açısından diğer Avrupa ülkelerinin gerisinde kalmış olan ve yerel tohum problemi yaşayan ülkemiz için oldukça kayda değer bir bulgu olarak dikkat çekmektedir. Araştırıcılar bu zenginliğin ıslah anlamında çok büyük avantajlar oluşturacağına dikkat çekmişlerdir (Poehlman, 2013; Smýkal ve ark., 2015). 
Benzer primerlerin kullanıldığ 1 bilimsel araştırmalarda görülen değerler, mevcut çalışma verileri ile yüksek oranda benzerlik göstermektedir (George ve ark., 2006; Zhang ve ark., 2010).

UPGMA yöntemi kullanılarak elde edilen filogenetik dendrogram incelendiğinde; populasyonların üç grup altında toplandıkları görülmektedir (Şekil 1). İlk grupta; yaklaşık 1500 $\mathrm{m}$ rakım civarından toplanan ve çalışmadaki en yüksek rakımlardan toplanan populasyonlar olan V1, O3 ve R2 kodlu populasyonların yer almas1 oldukça kayda değer bir durum olarak göze çarpmaktadır. Coğrafik olarak düşünüldüğünde nispeten daha yakın olan O3 ve R2 kodlu populasyonlar grup içinde birbirine daha yakın genetik özellik göstermişlerdir. İkinci grup bünyesinde en fazla ( 9 adet) populasyonu içermesi nedeniyle dikkat çekmektedir. Grup içerisinde diğer populasyonlara nazaran ayrı bir küme oluşturan ve birbirine en yakın genetik özellik gösteren Ç3 ve D1 kodlu populasyonlar ilk grupta olduğu gibi benzer rakım seviyelerinden (610 ve $636 \mathrm{~m}$ ) toplanan örneklerdir. Grup içerisinde Ç3 ve D1 kodlu populasyonlardan sonra birbirine en yakın genetik özellik gösteren populasyonlar Gaziantep ilinden toplanan G1 ve G2 kodlu populasyonlar olmuştur. Filogenetik dendrogramda üçüncü grup incelendiğinde; toplanma bölgeleri açısından diğer örneklere nazaran birbirine daha yakın illerden ve benzer rakım seviyelerinden toplanan D2, K1 ve K2 kodlu populasyonların bu grubu oluşturduğu tespit edilmiştir. Yapılan kümeleme analizi genel anlamda değerlendirilecek olursa; yüksek çeşitlilik gösteren, rakım seviyeleri ve coğrafik bölge ile ilişkili bir filogenetik dendrogram elde edildiği söylenebilir (Şekil 1).

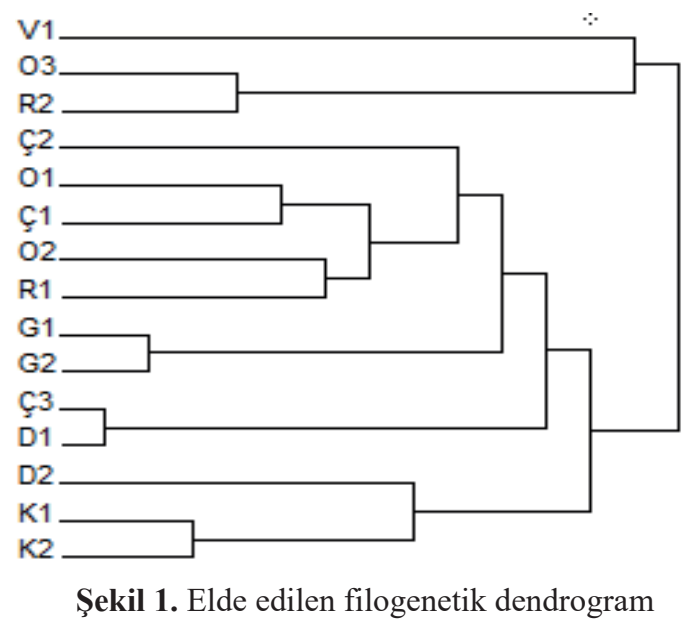

\section{Sonuçlar}

Genetik kaynakların korunması ve kullanılması anlamında yapılması gereken ilk işlem, bu kaynakların tanımlanması ve ıslah çalışmalarında başlangıç materyalinin belirlenmesi için birbirleri ile olan farklılıklarının ortaya konmasıdır. Çalışmada, toplanan ak üçgül populasyonlarının genetik farklılıkları ortaya konmuştur ve yüksek oranda çeşitlilik gösterdikleri tespit edilmiştir. $\mathrm{Bu}$ durum önümüzdeki yıllarda sürdürülebilecek ıslah çalışmalarında ülkemizde bulunan mevcut materyalden faydalanılabileceğini göstermektedir.

Çalışma neticesinde yüksek çeşitlilik gösteren populasyonların verim, kalite ve dayanıklılık yönünden değerlendirilmesi kanaatine varılmıştır. Yem bitkilerinde tohum sorununun üst düzeyde yaşandığ1 ülkemizde, genetik hazinede var olan kaynakları ortaya çıkararak, yeni yem bitkisi çeşitlerinin geliştirilmesi ve dışa bağımlılığın azaltılması ülkemiz tarımı adına mutlak bir vazifedir.

\section{Kaynaklar}

Acar, Z., Ayan, İ., 2012. Yem Bitkileri Kültürü. Ondokuz Mayıs Üniversitesi Ziraat Fakültesi Ders Kitab1, No: 2, Samsun.

Açıkgöz, E., 2001. Yem Bitkileri (Yenilenmiş 3. Bask1). Uludağ Üniversitesi Vakfi Yayın No: 182, Bursa.

Açıkgöz, E., Hatipoğlu, R., Altınok, S., Sancak, C., Tan, A., Uraz, D., 2005. Yem bitkileri üretimi ve sorunları. Türkiye Ziraat Mühendisliği VI. Teknik Kongresi, 3-7 Ocak, Ankara, s. 503-518.

Finne, M.A., Rognli, O.A., Schjelderup, I., 2000. Genetic variation in a Norwegian germplasm collection of white clover (Trifolium repens L). Euphytica, 112(1): 33-44.

George, J., Dobrowolski, M.P., Van Zijll de Jong, E., Cogan, N.O., Smith, K.F., Forster, J.W., 2006. Assessment of genetic diversity in cultivars of white clover (Trifolium repens L.) detected by SSR polymorphisms. Genome, 49(8): 919-930.

Gustine, D.L., Voigt, E.C., Brummer, P.W., Papadopoulos, Y.A., 2002. Genetic variation of RAPD markers for North American white clover collections and cultivars. Crop Science, 42(2): 343347.

Gündüz, H., 2013. Kuzeydoğu Anadolu Bölgesi populasyonlarından seçilen yem bezelyesi hatlarının bazı morfolojik ve tarımsal özellikleri. Yüksek Lisans Tezi, Atatürk Üniversitesi, Fen Bilimleri Enstitüsü, Erzurum.

Jones, E.S., Hughes, L.J., Drayton, MC., Abberton, M.T., Michaelson-Yeates T.P.T., Bowen, C., Forster, J.W., 2003. An SSR and AFLP molecular marker-based genetic map of White clover (Trifolium repens L.). Plant Science, 165(3): 531539.

Lefort, F., Lally, M., Thompson, D., Douglas, G.C., 1998. Morfolojical traits microsatellite fingerprinting and genetic relatedness of a stand of elite oaks (Q. Robur L.) at Tuallynally, Ireland. Silvae Genetica, 47(5): 5-6. 
Mercan, L., 2010. Yerli tavuk genotiplerinin ticari genotipler ile olan genetik farklılığının SSR (Simple Sequence Repeats- Basit Dizi Tekrarları) yöntemi ile analizi. Doktora Tezi, Ondokuz Mayıs Üniversitesi, Fen Bilimleri Enstitüsü, Samsun.

Poehlman, J.M., 2013. Breeding Field Crops. Springer Science \& Business Media, New York.

Smýkal, P., Coyne, C.J., Ambrose, M.J., Maxted, N., Schaefer, H., Blair, M.W., Berger, J., Greene, S.L., Nelson, M.N., Besharat, N., Vymyslický, T., Toker, C., Saxena, R.K., Roorkiwal, M., Pandey, M.K., Hu, J., Li, Y.H., Wang, L.X., Guo, Y., Qiu, L.J., Redden, R.J., Varshney, R.K., 2015. Legume crops phylogeny and genetic diversity for science and breeding. Critical Reviews in Plant Sciences, 34 (1-3): 43-104.
Toro, M.A., Fernandez, J., Caballero, A., 2009. Molecular characterization of breeds and its use in conservation. Livestock Science, 120(3): 174-195.

Treuren, R.V., Bas, N., Goossens, P.J., Jansen, J., Soest, L.J.M.V., 2005. Genetic diversity in perennial ryegrass and white clover among old Dutch grasslands as compared to cultivars and nature reserves. Molecular Ecology, 14(1): 39-52.

Zhang, X., Zhang, Y.J., Yan, R., Han, J.G., FuzengHong, F., Cao, K., 2010. Genetic variation of white clover (Trifolium repens L.) collections from China detected by morphological traits, RAPD and SSR. African Journal of Biotechnology, 9(21): 30323041. 